\title{
PENANDA KATA GANTI ORANG DALAM BAHASA TERNATE
}

\section{MARKER OF PERSONAL PRONOUNS IN TERNATE LANGUAGE}

\author{
Ety Duwila* dan Nurfani** \\ * Program Studi Sastra Indonesia, Fakultas Ilmu Budaya, Universitas Khairun \\ Jalan Jusuf Abdulrahman, Kelurahan Gambesi, Ternate, Indonesia \\ (085240067947, Ety_duwila@yahoo.com) \\ **Program Studi Sastra Inggris, Fakultas Ilmu Budaya, Universitas Khairun \\ Jalan Jusuf Abdulrahman, Kelurahan Gambesi, Ternate, Indonesia \\ (081343409100, fla_damayanti@yahoo.com)
}

\begin{abstract}
Abstrak
Penelitian ini dimaksudkan untuk mendeskripsikan penanda kata ganti orang dalam bahasa Ternate. Sebagai bahasa etnik, bahasa Ternate memiliki keunikan tersendiri. Bahasa Ternate memiliki keunikan tata bahasa yang berbeda dengan bahasa lainnya. Dengan menggunakan metode deskriptif kualitatif, penelitian ini berhasil mengungkapkan bahwa dalam bahasa Ternate terdapat bentuk-bentuk kata ganti orang, yaitu fajaru, fangare, ngori, ngom, ngone, ngon, ngana, una, mina, dan ana yang merupakan morfem bebas sehingga dalam kalimat dapat berdiri sendiri dan dalam kalimat aktif mengisi fungsi subjek (S). Selain itu, dalam bahasa ini juga terdapat bentuk penanda kata ganti orang yang kedudukannya dalam tuturan maupun secara gramatika tidak dapat berdiri sendiri. Meskipun demikian, bentuk terikat ini memiliki arti leksial, yaitu sebagai penanda kata ganti orang. Bentuk-bentuk penanda kata ganti orang BT adalah: to(penanda pronomina persona pertama tunggal), mi- (penanda pronomina persona pertama jamak eksklusif), si- (penanda pronomina persona pertama jamak inklusif), no- (penanda pronomina persona kedua tunggal), $n i$ - (penanda pronomina persona kedua jamak), $o$ - (penanda pronomina persona ketiga tunggal), dan $i$ - (penanda pronomina persona ketiga jamak).
\end{abstract}

Kata kunci: bahasa Ternate, kata ganti orang, penanda kata ganti orang

\begin{abstract}
This research is aimed ti describe marker of personal pronouns in Ternate language. As an ethnic language, Ternate language has its own uniqueness. Ternate language has the unique grammatical that is different from other languages. By using the descriptive qualitative methods, this study succeeded in revealing that in Ternate language there were forms of pronouns, namely fajaru, fangare, ngori, ngom, ngone, ngon, ngana, una, mina, and ana which are free morphemes, so that in sentences can stand alone and in active voice fill the function of Subject (S). In addition, in this language there are also markers of personal pronouns whose position both in speech and grammatically cannot stand alone in sentences but are attached to other forms. However, this bound form has a lexical meaning, which is a marker of personal pronouns. The markers of BT pronouns are: to- (marker of first singular personal pronoun), mi- (marker of first plural exclusive personal pronouns), si- (marker of first plural inclusive personal pronouns), no- (marker of second singular personal pronouns), no- (marker of second plural personal pronouns), o- (marker of third singular personal pronoun), and $i$ - (marker of third plural personal pronoun).
\end{abstract}

Keywords: Ternate language, personal pronouns, marker of personal pronouns 


\section{Pendahuluan}

Bahasa adalah salah satu unsur dalam kajian kebudayaan. Sebagaimana pengelompokan yang dilakukan Koentjaraningrat (1990), dari tujuh unsur kebudayaan, salah satunya adalah bahasa. Bahasa menjadi bagian terpenting dari kehidupan manusia karena dapat menjadi wadah interaksi. Pada praktiknya, setiap komunitas memiliki bahasa masing-masing karena dahulu masyarakat hidup berkelompokkelompok. Kelompok-kelompok itu masih sangat sulit berinteraksi antara satu kelompok dengan kelompok lainnya semudah saat ini karena terbatas dengan lingkungan geografis dan akses. Oleh karena itu, kajian kebahasaan sangat kaya untuk diteliti.

Grimes (2002) menyebutkan bahwa bahasa daerah di Maluku Utara berjumlah 28 bahasa. Pemetaan bahasa-bahasa di Maluku Utara oleh Fakultas Sastra dan Budaya, Universitas Khairun (2008) menyebutkan bahwa jumlah bahasa daerah di Maluku Utara sebanyak 33 bahasa. Terbaru, inventarisasi yang dilakukan Kantor Bahasa Maluku Utara (2011) menyimpulkan bahwa jumlah bahasa daerah yang ada di Provinsi Maluku Utara sebanyak 36 bahasa.

Ketiga penelitian tersebut dapat disimpulkan bahwa jumlah bahasa daerah di Provinsi Maluku Utara berbeda-beda. Sejumlah kalangan, melalui berbagai diskusi, menyebutkan jumlah tersebut tidak mencapai 20-an bahasa. Hal ini didasarkan pada pandangan bahwa ada sejumlah bahasa di Maluku Utara yang memiliki tingkat kesamaan kata yang tinggi. Menurut Ibrahim, tingkat kesamaan kosakata pada bahasa-bahasa itu mencapai 80 persen. Penutur bahasa-bahasa itu sudah pasti saling memahami, tetapi ada semacam ego sektoral yang memandang bahasa yang hidup di lingkungan mereka memiliki keunikan tersendiri sehingga layak dianggap sebagai bahasa tersendiri. Pada kasus bahasa Makeang Timur (Makeang Dalam) dan Kayoa (Ngeilo), misalnya, kedua penutur bahasa ini pada dasarnya saling memahami, tetapi dalam pemetaan bahasa atau inventarisasi bahasa-bahasa di Maluku Utara sebagaimana tiga penelitian yang disebutkan tersebut menegaskan bahwa Makeang Timur dan Kayoa adalah dua bahasa yang berbeda.

Terkait dengan jumlah, simpulan beberapa penelitian tersebut, secara metodologis memiliki argumentasi masingmasing yang dapat dipertanggungjawabkan dalam menentukannya sebagai sebuah bahasa atau bukan. Hal yang patut dicermati adalah ketiganya membentangkan satu garis kecenderungan yang sama, yakni bahasabahasa di Maluku Utara-jika diukur dari tiga penelitian tersebut-secara diakronis jumlahnya bergerak naik dari satu penelitian ke penelitian lain. Menurut Kepala Kantor Bahasa Maluku Utara, Syarifuddin (2019) dalam satu kesempatan diskusi terbatas, jumlah itu bahkan bisa bertambah jika dilakukan inventarisasi kembali.

Dari jumlah bahasa itu, salah satunya adalah bahasa Ternate yang menjadi objek penelitian ini. Secara historis, bahasa Ternate (selanjutnya disingkat BT) dianggap sebagai bahasa kolano, 'bahasa raja', bahasa yang dipakai dalam komunikasi dengan pihak kerajaan atau kesultanan (Ibrahim, 2009: 120). Sebagai bahasa raja, bahasa Ternate secara tidak langsung menjadi basantara (lingua-franca) bagi semua etnik di Maluku Utara pada zaman dahulu. Kini bahasa Ternate hanya berlaku pada kantong-kantong penggunanya sebagai bahasa etnik karena bahasa Melayu Ternate sudah menggantikan perannya sebagai basantara.

Sebagai bahasa etnik, bahasa Ternate memiliki keunikan tersendiri. Sebagaimana yang akan menjadi fokus penelitian ini, dalam bahasa Ternate, bentuk kata yang menduduki fungsi predikat mengalami proses morfologis (variasi baru) ketika kata ganti orang yang mengisi fungsi subjek berubah. Dalam bahasa Indonesia, proses morfologis semacam ini tidak terjadi. Misalnya, saya datang dan mereka datang. Kata kerja datang tetap memiliki konfigurasi atau bentuk yang sama meskipun kata ganti orang (pronomina persona) mengalami penyesuaian dari 'saya' ke 'mereka.' Contoh ini menegaskan salah satu bagian tentang bahasa. Jika ditelusuri lebih jauh, ada banyak aspek yang dapat 
memperlihatkan ciri pembeda di antara banyaknya bahasa tersebut.

Semua bahasa pada dasarnya memiliki pola-pola dasar yang dapat dijelaskan, termasuk bahasa Ternate. Setiap bahasa memiliki ciri khas tertentu yang membedakannya dari bahasa lain. Ciri khas ini dapat berbentuk bunyi, kata, frasa, kalimat, ataupun dari segi suprasegmentalnya. Bahasa Ternate juga memiliki ciri-ciri khas yang membedakannya dari bahasa lain. Misalnya,

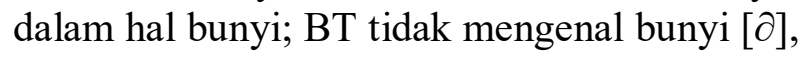
dalam hal pembentukkan kata; BT memiliki bentuk penanda kata ganti orang; dan kata-kata dalam BT cendrung berakhir dengan vokal (ciri bahasa vokalis, kecuali bunyi nasal itu pun sebagian kecil saja. Mengenai pembentukan kata BT cukup menarik untuk dikaji karena selain merupakan kajian morfologi juga sekaligus melibatkan kajian sintaksis. Hal ini dapat terjadi karena ujaran berupa kalimat meskipun itu hanya kalimat sederhana SP (subjek-predikat) dibentuk (kajian sintaksis), akan sekaligus terbentuk kata kompleks (bentuk dasar + bentuk terikat) yang mengisi fungsi predikat. Sebagai contoh, kalimat Fajaru totagi toma gura dapat dianalisis sebagai berikut: fungsi subjek (S) diisi oleh Fajaru 'orang pertama tunggal perempuan', fungsi predikat $(\mathrm{P})$ diisi oleh totagi 'pergi', dan fungsi keterangan (Ket) diisi oleh toma gura 'ke kebun'. Kata totagi yang mengisi fungsi predikat berkategori verbal yang bermakna 'pergi' terbentuk dari bentuk dasar tagi 'pergi' dan bentuk terikat to $=$ sebagai penanda kata ganti orang pertama tunggal.

Ada banyak pola-pola dasar bahasa Ternate yang secara lingusitik dapat dijelaskan. Akan tetapi, dalam penelitian ini, kajian hanya difokuskan pada kajian tentang pronomina persona dan pemarkah pronomina persona yang menjadi salah satu ciri keunikan bahasa Ternate.

Secara garis besar, penelitian ini menggunakan dua konsep besar, yakni morfologi dan sintaksis. Morfologi dipakai untuk memahami proses pembentukan kata, sementara sintaksis digunakan sebagai acuan melihat proses pembentukan sebuah kalimat.
Dengan menggunakan dua konsep ini, perubahan-perubahan yang terjadi pada bentuk dasar atau kata-kata bentukan dapat diidentifikasi perannya.

Rochelle Lieber dalam introduction morphology mengatakan bahwa morphology is the study of word formation, including the ways new words are coined in the languages of the world, and the way forms of the words are varied depending on how they are used in sentences (2009: 2). Pandangan ini mengarahkan kita pada satu pemahaman bahwa fokus utama kajian morfologi adalah kata atau variasi kata yang dikembangkan menjadi kata-kata baru berdasarkan kebutuhan penutur dalam setiap tindak tuturnya (speech $a c t$ ).

Hal yang sama juga dikemukakan Abdul Chaer. Secara detail, Chaer (2008: 3) menjelaskan bahwa morfologi sebenarnya berasal dari dua kata, yakni morf yang berarti 'bentuk' dan logi yang berarti 'ilmu'. Dengan demikian, secara harfiah, morfologi adalah ilmu mengenai bentuk. Di dalam linguistik, bentuk yang dimaksudkan adalah bentukbentuk atau pembentukan kata.

Sementara Ramlan (2001), secara sederhana menjelaskan bahwa konsep tetang morofologi adalag ilmu yang mempeajari tentang pembentukan kata.

Dalam sebuah analisis morfologi, satuan terkecil baik yang sudah menjadi kata atau belum menjadi kata perlu diuraikan karena itu semua merupakan titik awal proses pembentukan sebuah kata. Dengan demikian, bentuk kata dasar dan proses pembentukan selanjutnya dapat dideskripsikan.

Selanjutnya, konsep kedua yang digunakan dalam penelitian ini adalah sintaksis. Ada banyak batasan sintaksis yang dikemukakan oleh para linguis, salah satunya adalah Abdul Chaer. Menurutnya, sintaksis adalah subsistem yang membicarakan penataan dan pengaturan kata-kata itu ke dalam satuan-satuan yang lebih besar, yang disebut satuan-satuan sintaksis Chaer (2009: 3).

Menurut Kridalaksana (2007) kata sebagai satuan terbesar dalam kajian morfologi merupakan satuan yang juga dibicarakan di 
dalam kajian sintaksis sebagai pembentuk satuan bahasa yang lebih besar, seperti frasa, klausa dan kalimat. Kata dapat dikategorikan berdasarkan perilakunya dalam satuan yang lebih besar. Sebuah kata dikatakan berkategori verba, misalnya hanya dari perilakunya dalam frasa. Ciri-ciri setiap kata dapat dijelaskan dari sudut sintaksis. Untuk itu, dapat ditentukan kelas kata dalam sebuah bahasa.

Di antara pembagian kelas kata tersebut di atas, terdapat kelas kata ganti orang (pronominal persona). Pronomina persona adalah pronominal yang dipakai untuk mengacu pada orang. Pronomina dapat mengacu pada diri sendiri, pada orang yang diajak bicara, maupun mengacu pada orang yang dibicarakan. Pada kajian sintaksis kata ganti orang ini biasanya menduduki fungsi Subjek. Dalam beberapa bahasa (termasuk dalam bahasa Ternate), dalam membentuk kalimat terdapat bentuk penanda kata ganti orang (pemarkah persona). Penanda ini berubah-ubah sesuai dengan kata ganti yang menduduki fungsi subjek (Alwi dkk., 2003).

\section{Metode Penelitian}

Metode yang digunakan dalam penelitian ini adalah kualitatif deskriptif. Metode itu dipilih karena berkaitan dengan tujuan penelitian ini, yakni memperlihatkan wujud kata ganti orang dan penanda kata ganti orang pada bahasa Ternate. Dengan pendekatan ini, data-data kualitatif akan didapatkan dengan mudah dan selanjutnya disajikan dalam bentuk deskriptif.

Data-data yang dikumpulkan bersumber dari lapangan, yaitu dengan cara menggunakan metode simak, cakap, rekam, catat, dan instrumen. Sementara itu, pemilihan informan dilakukan secara snow-balling sehingga jumlanya tidak terbatas dan bergantung pada kebutuhan analisis.

Selanjutnya, data-data yang dikumpulkan akan dianalisis dan disajikan disertai dengan contoh kalimat. Penjelasan harus disertai kalimat karena penanda kata ganti orang tidak bisa berdiri sendiri.

\section{Pembahasan}

\subsection{Kata Ganti Orang Bahasa Ternate}

Dalam bahasa Ternate, kata ganti orang mengenal pengkelaminan kata, artinya kata ganti ada yang disesuaikan dengan jenis kelamin, seperti untuk menyatakan kata ganti orang pertama tunggal dan kata ganti orang ketiga tunggal dan ada yang pemakaiannya boleh ditujukan untuk laki-laki maupun sekaligus perempuan, seperti untuk menyatakan kata ganti orang kedua tunggal. Dalam kamus bahasa Ternate karangan Atjo (2008) disebutkan bahwa untuk menyatakan kata ganti orang pertama tunggal perempuan digunakan bentuk fajaru dan untuk menyatakan kata ganti orang pertama tunggal laki-laki digunakan fangare. Pemakaian kedua kata ganti orang tersebut dapat dilihat pada contoh (1) dan (2) berikut.

(1) Fajaru to- uto tamate se rica kg1t(pr)p1t menanam tomat KONJ cabai

'Saya (pr) menanam tomat dan cabai di kebun'

$\begin{array}{llll}\text { (2) Fangareto- } & \text { tagi toma } & \text { bane } \\ \text { kg1t(lk)p1t pergi } & \text { PREP } & \text { pantai } \\ \text { 'Saya (lk) pergi ke pantai' } & \end{array}$

Kedua bentuk pronomina persona tersebut (fajaru/fangare) digunakan apabila lawan bicaranya dianggap sebagai orang yang dihormati pada saat bertutur dengan lawan tutur yang sepadan maka digunakan bentuk ngori, baik untuk laki-laki maupun perempuan, seperti dalam kalimat (3) berikut.

\section{(3) Ngori to- tego toma dego- \\ kg1t p1t duduk PREP tempat}

'Saya (pr dan lk) duduk di tempat duduk'

Kata ganti orang pertama jamak dalam bahasa Ternate terdiri atas dua bentuk, yaitu ngom dan ngone. Bentuk ngom bersifat eksklusif; artinya kata ganti orang pertama jamak ini mencakupi pembicara atau penulis dan orang lain di pihaknya, tetapi tidak mencakupi orang lain di pihak pendengar atau pembacanya. Sebaliknya, bentuk ngone 
bersifat inklusif; artinya, kata ganti orang pertama jamak ini mencakupi tidak saja pembicara/penulis, tetapi juga pendengar/pembicara, dan mungkin pula pihak lain. Penggunaan kedua bentuk kata ganti ini dapat dilihat pada contoh kalimat (4) dan (5).

(4) Ngom mi- kudiho toma fala kg1j(eks) p1j(eks) Pulang PREP rumah

'Kami pulang ke rumah'

$\begin{array}{lll}\text { (5) } & \text { Ngone } \quad \text { si- } & \text { lamo fala } \\ \text { Kg1j(ink) } & \text { plj(ink) } & \text { besar rumah } \\ & \text { 'Kita besarkan rumah' } & \end{array}$

Pronomina persona kedua tunggal BT, ngana digunakan dalam percakapan, baik untuk laki-laki maupun perempuan, seperti terlihat pada contoh (6) dan (7) berikut ini.
(6) Ngana no- Dahe Lefo kg2t p2t Dapat Buku
'Kamu mendapat buku'
(7) Ngana no- Tagi sekola. kg2t p2t Dapat Buku
'Kamu pergi ke sekolah'

Kata ganti orang kedua bahasa Ternate mempunyai bentuk jamak, yaitu ngon. Penggunaan bentuk ini dapat dilihat dalam kalimat (8) dan (9) berikut.

(8) Ngon ni- uto koi toma $\begin{array}{lll}\text { gura } & & \\ \mathrm{kg} 2 \mathrm{j} & \mathrm{p} 2 \mathrm{j} \text { menanam pisang }\end{array}$ PREP kebun

'Kalian menanam pisang di kebun'

(9) Ngon ni- oro bira bolo ua?

$\mathrm{kg} 2 \mathrm{j} \quad \mathrm{p} 2 \mathrm{j}$ ambil beras KONJ NEG?

'Kalian mengambil beras atau tidak'?

Kata ganti orang ketiga tunggal BT mempunyai dua bentuk yang disesuaikan dengan jenis kelamin, yaitu bentuk una, dipakai untuk menyatakan kata ganti orang ketiga tunggal laki-laki dan mina, dipakai untuk menyatakan kata ganti orang ketiga tunggal perempuan. Kedua bentuk kata ganti orang tersebut masing-masing dapat dilihat pada contoh kalimat (10) dan (11) berikut.

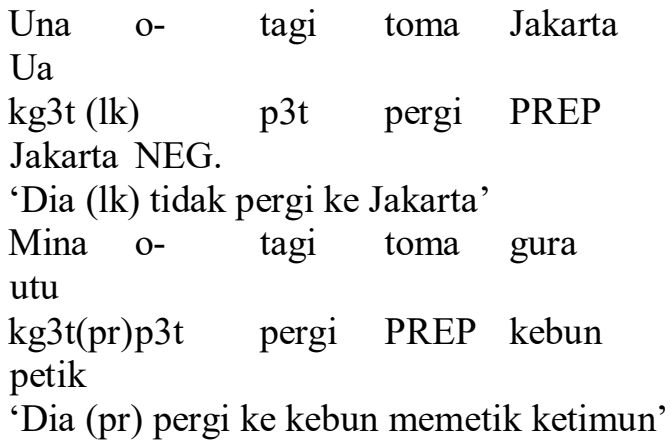

Kata ganti orang ketiga jamak bahasa Ternate adalah ana, seperti pada contoh kalimat (12) dan (13) berikut.

$$
\begin{aligned}
& \text { Ana i- sinanga koi se } \\
& \text { Bonci } 3 \text { j } \\
& \mathrm{kg} 3 \mathrm{j} \quad \mathrm{p} 3 \mathrm{j} \text { menggoreng pisang } \\
& \text { KONJ Kacang } \\
& \text { 'Mereka menggoreng pisang dan kacang' } \\
& \text { Ana i- tego toma dego-dego } \\
& \mathrm{kg} 3 \mathrm{j} \quad \mathrm{p} 3 \mathrm{j} \text { duduk PREP tempat } \\
& \text { duduk } \\
& \text { 'Mereka duduk di tempat duduk'. }
\end{aligned}
$$

\begin{tabular}{|c|c|c|c|c|}
\hline \multirow{3}{*}{$\begin{array}{c}\text { Per- } \\
\text { sona } \\
(\text { o- } \\
\text { ra- } \\
\text { ng) }\end{array}$} & \multicolumn{4}{|c|}{ Makna } \\
\hline & Tunggal & \multicolumn{3}{|c|}{ Jamak } \\
\hline & & Netral & Eksklusif & Inklusif \\
\hline $\begin{array}{l}\text { Perta } \\
\text {-ma }\end{array}$ & $\begin{array}{c}\text { fajaru } \\
\text { 'saya } \\
\text { (peremp } \\
\text { uan)' } \\
\text { fangare } \\
\text { 'saya } \\
\text { (laki- } \\
\text { laki)' } \\
\text { ngori } \\
\text { 'saya }\end{array}$ & & $\begin{array}{l}\text { ngom } \\
\text { 'kami' }\end{array}$ & $\begin{array}{l}\text { ngone } \\
\text { 'kita' }\end{array}$ \\
\hline
\end{tabular}

Berdasarkan data yang telah diuraikan dapat dikemukakan bentuk-bentuk kata ganti orang dalam bahasa Ternate seperti terlihat dalam bagan berikut.

\section{Bagan 1}

Pronomina Persona Bahasa Ternate 


\begin{tabular}{|l|c|c|l|l|}
\hline & $\begin{array}{c}\text { (peremp } \\
\text { uan atau } \\
\text { laki-laki } \\
\text { umum) }\end{array}$ & & & \\
& & & & \\
\hline $\begin{array}{c}\text { Ke- } \\
\text { dua }\end{array}$ & $\begin{array}{c}\text { ngana } \\
\text { 'kamu' }\end{array}$ & $\begin{array}{c}\text { ngon } \\
\text { 'kalian } \\
\text { Ke- }\end{array}$ & & \\
tiga & $\begin{array}{c}\text { una 'dia } \\
\text { laki- } \\
\text { laki' } \\
\text { mina } \\
\text { 'dia } \\
\text { perempu } \\
\text { an' }\end{array}$ & 'merek & & \\
& & & \\
& & & \\
\end{tabular}

Kata ganti orang BT tersebut memiliki fungsi sebagai salah satu pembentuk kalimat (pengisi fungsi subjek) yang dapat berdiri sendiri tanpa melekat pada bentuk lain atau pada morfem lain yang ada di lingkungannya, artinya kata ganti orang BT merupakan morfem bebas.

\subsection{Penanda Kata Ganti Orang Bahasa Ternate}

Penanda kata ganti orang atau pemarkah persona BT adalah bentuk terikat yang dalam tuturan maupun secara gramatikal tidak dapat berdiri sendiri melainkan melekat dengan bentuk lain. Meskipun tidak sanggup berdiri sendiri dalam tuturan ataupun secara gramatikal, bentuk ini memiliki arti leksikal, yaitu sebagai penanda kata ganti orang. Ketika yang berbicara adalah orang pertama tunggal perempuan, fajaru misalnya, maka bentuk penanda yang dipakai adalah bentuk to- ketika bentuk yang digunakan merupakan orang kedua tunggal, ngana maka dipakai bentuk nodan bentuk yang digunakan merupakan orang ketiga tunggal laki-laki, una maka dipakai bentuk $o$-. Untuk itu, dapat dikatakan bahwa bentuk-bentuk ini adalah bentuk klitik. Karena merupakan bentuk terikat, penanda kata ganti orang dalam BT melekat pada bentuk dasar yang mengisi fungsi predikat. Sebagai contoh dapat dilihat pada beberapa bentuk kalimat di bawah ini.

\subsubsection{Bentuk $i$ -}

Pemakaian bentuk penanda kata ganti orang ketiga jamak $i$ - dapat dilihat pada contoh (14) berikut.

$$
\begin{aligned}
& \text { (14) Ana i- tagi toma Gura } \\
& \text { kg3j p3j pergi PREP Kebun } \\
& \text { 'Mereka pergi ke kebun'. }
\end{aligned}
$$

Kalimat di atas dapat dianalisis sebagai berikut. Bentuk ana 'mereka' adalah kata ganti orang ketiga jamak yang mengisi fungsi subjek (S), $i$ - adalah bentuk penanda kata ganti orang ketiga jamak yang keberadaannya melekat pada bentuk dasar tagi 'pergi' yang mengisi fungsi predikat (P). Bentuk toma ' $\mathrm{ke}$ ' merupakan preposisi dan gura 'kebun' mengisi fungsi keterangan (Ket) dalam kalimat tersebut. Pemarkah persona ketiga jamak $i$ juga dapat dilihat pada contoh (15) dan (16) sebagai berikut.
(15) Ana i- uto tamate se
Rica
$\mathrm{kg} 3 \mathrm{j} \quad \mathrm{p} 3 \mathrm{j}$ tanam tomat KONJ
Cabai
'Mereka menanam tomat dan cabai'.

(16) Ana i- tego toma dego-dego kg3j p3j duduk PREP tempat duduk

'Mereka duduk di tempat duduk'.

Pada kalimat (15) dan (16), fungsi (S) diisi oleh ana 'mereka', fungsi (P) masingmasing diisi oleh $i$ - 'penanda kata ganti orang ketiga jamak' dan uto 'tanam' dan $i$ - 'penanda kata ganti orang jamak' dan tego 'duduk', dan fungsi (O) pada (15) diisi oleh tamate 'tomat', se 'dan' rica 'cabai', serta fungsi (Ket) pada (16) diisi oleh frase toma 'di' dan dego-dego 'tempat duduk'.

\subsubsection{Bentuk to-}

Penanda kata ganti orang pertama tunggal perempuan, fajaru dan penanda kata ganti pertama tunggal laki-laki, fangare, serta penanda kata ganti orang pertama tunggal netral, ngori adalah to- seperti terlihat pada contoh kalimat (17), (18), dan (19) di bawah ini. 
(17) Fajaru to- oho koi se igo $\mathrm{kg} 1 \mathrm{t}(\mathrm{pr}) \quad \mathrm{p}$ t makan pisang KONJ Kelapa

'Saya (pr) makan pisang dan kelapa'.

(18) Fangareto- utu guae toma fala mangara

kg1t(lk)plt memetik mangga

PREP rumah Depan

'Saya (pr) memetik mangga di depan rumah'.

(19) Ngori to- oho bira kg1t (pr atau lk)p1t Makan nasi 'Saya (pr atau lk) makan nasi'.

Pada kalimat (17), fungsi (S) diisi oleh kata fajaru orang ketiga tunggal perempuan diikuti kata tooho 'makan' yang merupakan bentuk kompleks karena terbentuk dari penanda kata ganti orang ketiga tunggal (to-) dan bentuk oho 'makan'. Bentuk kompleks ini mengisi fungsi $(\mathrm{P})$. Fungsi $(\mathrm{O})$ diisi oleh $k o i$ 'pisang, se 'dan', igo 'kelapa'. Fungsi (S) pada kalimat (18) diisi oleh fangare 'kata ganti orang ketiga tunggal perempuan' fungsi (P) diisi oleh kata toutu 'memetik' yang terbentuk dari to- 'penanda kata ganti orang ketiga tunggal' dan utu 'petik'. Kata guae 'mangga' mengisi fungsi $(\mathrm{O})$ dalam kalimat ini dan diikuti frase toma 'di', fala 'rumah', mangara 'depan' yang mengisi fungsi (Ket). Sementara pada kalimat (19), fungsi (S) diisi oleh ngori (kata ganti orang pertama tunggal baik lakilaki maupun perempuan), fungsi ( $\mathrm{P}$ ) diisi oleh tooho yang terbentuk dari bentuk dasar oho 'makan' dan bentuk penanda to-, serta fungsi (O) diisi oleh kata bira 'makan'.

\subsubsection{Bentuk mi-}

Penanda kata ganti orang pertama jamak eksklusif, ngom adalah bentuk mi-, seperti dalam kalimat (20) berikut.

(20) Ngom mi- Hotu raima Kg1j(eks) plj(eks) tidur sudah 'Kami sudah tidur'

Kalimat dapat dianalisis sebagai berikut; fungsi (S) diisi oleh ngom 'kata ganti orang pertama jamak', frase mihotu raima mengisi fungsi $(\mathrm{P})$ yang terbentuk dari bentuk dasar hotu 'tidur' dan $m i$ - sebagai penanda kata ganti orang pertama jamak dan bentuk kala raima 'sudah'.

\subsubsection{Bentuk ni-}

Untuk penanda kata ganti orang kedua jamak, ngon digunakan bentuk $n i$-, seperti contoh kalimat (21) di bawah ini.

$$
\begin{aligned}
& \text { Ngon ni- otu koi toma } \\
& \text { Gura } \\
& \text { kg2j p2j tanam pisang PREP } \\
& \text { Kebun } \\
& \text { 'Kalian menanam pisang di kebun'. }
\end{aligned}
$$

Kalimat tersebut berpola SPOK. Fungsi (S) diisi oleh ngon sebagai kata ganti orang kedua jamak, fungsi (P) diisi oleh bentuk niuto yang terbentuk dari bentuk dasar uto 'tanam' dan $n i$ - sebagai penanda kata ganti orang kedua jamak, fungsi (O) diisi oleh koi 'pisang', dan fungsi (Ket) di isi oleh frase toma gura 'di kebun'.

\subsubsection{Bentuk no-}

Bentuk no- merupakan penanda kata ganti orang kedua tunggal. Pemakaian bentuk ini seperti dalam kalimat (22) berikut.

$$
\begin{array}{llll}
\text { Ngana no- } & \text { gulaha ake } & \text { guraka } \\
\text { kg2t p2t buat air } & \text { jahe } \\
\text { 'Kamu membuat air jahe'. }
\end{array}
$$

Kalimat (22) terdiri atas bentuk ngana yaitu kata ganti orang kedua tunggal yang mengisi fungsi (S), bentuk nogulaha yang terbentuk dari bentuk dasar gulaha 'buat' dan no- sebagai penanda kata ganti orang kedua tunggal yang mengisi fungsi (P) dan kata majemuk ake guraka 'air jahe' yang mengisi fungsi $(\mathrm{O})$.

\subsubsection{Bentuk si-}

Penanda kata ganti orang pertama jamak inklusif yaitu bentuk si-. Pemakaian bentuk ini dapat dilihat pada contoh kalimat (23) berikut.

$$
\begin{aligned}
& \text { Ngone si- waho Koi ne } \\
& \text { kgij(ink) } \quad \text { p1j(ink)hancur pisang } \\
& \text { DET } \\
& \text { Kami menghancurkan pisang ini'. }
\end{aligned}
$$


Kalimat tersebut di atas berpola SPO. Fungsi (S) diisi oleh ngone sebagai kata ganti orang pertama jamak inklusif, fungsi $(\mathrm{P})$ diisi oleh kata siwaho yang terbentuk dari bentuk dasar waho 'hancur' dan bentuk si- sebagai penanda kata ganti orang pertama jamak inklusif, dan fungsi $(\mathrm{O})$ diisi oleh frase koi ne yang bermakna pisang ini.

\subsubsection{Bentuk o-}

Bentuk o- dipakai sebagai penanda kata ganti orang ketiga tunggal baik laki-laki, una atau perempuan, mina. Pemakaian kedua bentuk penanda tersebut dapat dilihat pada contoh (24) dan (25) berikut.

\begin{tabular}{|c|c|c|c|}
\hline (24) & $\begin{array}{l}\text { Una o- } \\
\text { kg3t(lk) } \\
\text { Tidore }\end{array}$ & $\begin{array}{l}\text { tagi } \\
\text { p3t }\end{array}$ & $\begin{array}{l}\text { toma } \\
\text { pergi }\end{array}$ \\
\hline & 'Dia (laki- & pergi ke & Tidore \\
\hline (25) & $\begin{array}{l}\text { Mina o- } \\
\text { kg3t(pr) }\end{array}$ & $\begin{array}{l}\text { kudiho } \\
\text { p3t }\end{array}$ & $\begin{array}{l}\text { Raima } \\
\text { pulang }\end{array}$ \\
\hline
\end{tabular}

Kalimat (24) dan (25) dapat dianalisis sebagai berikut. Fungsi (S) pada kedua kalimat tersebut masing-masing diisi oleh Una sebagai kata ganti orang ketiga tunggal laki-laki dan mina sebagai kata ganti orang ketiga perempuan. Fungsi (P) pada kalimat (24) diisi oleh otagi yang terbentuk dari bentuk dasar tagi 'pergi' dan bentuk $o$ - sebagai penanda kata ganti orang dan pada kalimat (25) diisi oleh frasa okudiho raima yang terdiri atas kata kata okudiho 'pulang' dan raima 'sudah'. Kata okudiho terbentuk dari kata kudiho 'pulang' dan bentuk dasar $o$ - sebagai penanda kata ganti ketiga tunggal. Sementara itu, fungsi (Ket) pada (25) diisi oleh frasa toma Tidore 'di Tidore'.

Bentuk-bentuk penanda kata ganti orang BT seperti yang telah diuraikan sebelumnya dapat dibagankan sebagai berikut.

\section{Bagan 2}

Pemarkah Pronomina Persona BT

\begin{tabular}{|l|l|}
\hline $\begin{array}{l}\text { Penan- } \\
\text { da } \\
\text { kata } \\
\text { ganti } \\
\text { orang }\end{array}$ & Makna \\
\hline
\end{tabular}

\begin{tabular}{|l|c|c|c|c|}
\hline & $\begin{array}{c}\text { Tung- } \\
\text { gal }\end{array}$ & \multicolumn{3}{|c|}{ Jamak } \\
\hline & & Netral & Eksklusif & Inklusif \\
\hline $\begin{array}{l}\text { Per- } \\
\text { tama }\end{array}$ & to- & & mi- & si- \\
\hline Kedua & no- & ni- & & \\
\hline Ketiga & o- & i- & & \\
\hline
\end{tabular}

\section{Simpulan}

Berdasarkan analisis data dapat disimpulkan bahwa dalam bahasa Ternate terdapat bentukbentuk kata ganti orang, yaitu fajaru, fangare, ngori, ngom, ngone, ngon, ngana, una, mina, dan ana yang merupakan morfem bebas sehingga dalam kalimat dapat berdiri sendiri dan dalam kalimat aktif mengisi fungsi Subjek (S). Selain itu, dalam bahasa ini juga terdapat bentuk penanda kata ganti orang yang kedudukannya, baik dalam tuturan maupun secara gramatikal, tidak dapat berdiri sendiri dalam kalimat tetapi melekat pada bentuk lain. Meskipun demikian, bentuk terikat ini memiliki arti leksikal, yaitu sebagai penanda kata ganti orang. Bentuk-bentuk penanda kata ganti orang BT adalah: to-, mi-, si-, no-, ni-, $o-$, dan $i$-.

\section{Daftar Pustaka}

Alwi, Hasan, dkk. (2003). Tata Bahasa Baku bahasa Indonesia. Jakarta: Balai Pustaka.

Atjo, Rusli Andi. (2008). Kamus Ternate Indonesia. Jakarta: Cikoro Printing.

Chaer, Abdul. (2009). Sintaksis Bahasa Indoensia (Pendekatan Proses). Jakarta: PT Rineka Cipta.

Chaer, Abdul. (2008). Morfologi Bahasa Indonesia (pendekatan proses). Jakarta: Rineka Cipta.

Fokaaya, Nurhayati, dkk. (2014). BahasaBahasa Daerah di Maluku Utara. Kantor Bahasa Maluku Utara, Provinsi Maluku Utara.

Grimes, Barbara A. (ed). (2002). Ethnologue: Languages of the World. Dallas, Texas: SIL International

Ibrahim, Gufran A. (2009). Metamorfosa Sosial dan Kepunahan Bahasa. Ternate: LepKhair 
Koentjaraningrat. (1990). Pengantar Ilmu Antropologi. Jakarta: Rineka Cipta.

Kridalaksana, Harimurti. (2007). Kelas Kata

Dalam Bahasa Indonesia. Jakarta: PT Gramedia Pustaka Utama

Latif, Rainannur, dkk. (2008).Pemetaan Bahasa Daerah di Maluku Utara: Sebaran, Pemerolehan, dan Pola Penggunaan. Kerjasama Badan Perencanaan Pembangunan Daerah
(Bappeda) Provinsi Maluku Utara Dengan Fakultas Sastra Dan Budaya Universitas Khairun.

Lieber, Rochelle. (2009). Introduction Morphology. Cambridge University Press

Ramlan, M. (2002). Morfologi Suatu Tinjauan Deskriptif. Jogjakarta: CV Karyono. 